\title{
Metabolic Risk Factors of Sporadic Alzheimer's Disease: Implications in the Pathology, Pathogenesis and Treatment
}

\author{
Sasanka Chakrabarti*1, Vineet Kumar Khemka ${ }^{1}$, Anindita Banerjee ${ }^{1,2}$, Gargi Chatterjee ${ }^{1}$, \\ Anirban Ganguly ${ }^{1}$, Atanu Biswas ${ }^{3}$.
}

\begin{abstract}
${ }^{1}$ Department of Biochemistry, Institute of Post Graduate Medical Education and Research, Kolkata, India.
${ }^{2}$ Department of Biochemistry, ICARE Institute of Medical Sciences and Research, Haldia, India.

${ }^{3}$ Department of Neuromedicine, Bangur Institute of Neurosciences (BIN), Kolkata, India.
\end{abstract}

[Received July 30, 2013; Revised September 30, 2014; Accepted October 2, 2014]

\begin{abstract}
Alzheimer's disease (AD), the major cause of dementia among the elderly world-wide, manifests in familial and sporadic forms, and the latter variety accounts for the majority of the patients affected by this disease. The etiopathogenesis of sporadic AD is complex and uncertain. The autopsy studies of AD brain have provided limited understanding of the antemortem pathogenesis of the disease. Experimental AD research with transgenic animal or various cell based models has so far failed to explain the complex and varied spectrum of AD dementia. The review, therefore, emphasizes the importance of AD related risk factors, especially those with metabolic implications, identified from various epidemiological studies, in providing clues to the pathogenesis of this complex disorder. Several metabolic risk factors of AD like hypercholesterolemia, hyperhomocysteinemia and type 2 diabetes have been studied extensively both in epidemiology and experimental research, while much less is known about the role of adipokines, proinflammatory cytokines and vitamin $D$ in this context. Moreover, the results from many of these studies have shown a degree of variability which has hindered our understanding of the role of AD related risk factors in the disease progression. The review also encompasses the recent recommendations regarding clinical and neuropathological diagnosis of AD and brings out the inherent uncertainty and ambiguity in this area which may have a distinct impact on the outcome of various population-based studies on AD-related risk factors.
\end{abstract}

Key words: Metabolic, risk factors, sporadic, Alzheimer's disease, pathogenesis, treatment

With the general increase in the life span of the population across the globe, Alzheimer's disease (AD), a progressive neurodegenerative disorder presenting with insidious loss of memory and cognition, is fast becoming a major disease burden and socio-economic challenge for many countries. $\mathrm{AD}$ is the commonest form of dementia above the age of 65 years, and the estimated prevalence of this disease was 24 million in the world in 2011 which would be doubled by the year $2030[1,2]$. The majority (more than $95 \%$ ) of the AD dementia cases belong to sporadic variety of the disease which is a multi-factorial disorder in which both genetic predisposition and environmental factors contribute to the genesis of the disease $[1,2,3]$. In contrast, the familial form of the disease (less than 5\% of $\mathrm{AD}$ population) arises from the mutations of any of the three genes e.g. amyloid precursor protein $(A P P)$, presenilin 1 ( $P S 1)$ and presenilin 2 (PS 2) and usually appears in somewhat younger age-group than the sporadic form and follows a more aggressive downhill course [2, $3,4]$. The clinical features and post-mortem 
neuropathological hallmarks of both forms of $\mathrm{AD}$ are nearly identical, and thus it has been tacitly assumed that ante-mortem pathogenesis is the same in either form of the disease. The neuropathological lesions of $\mathrm{AD}$ are characterized by abnormal accumulation of amyloid beta protein $(\mathrm{A} \beta)$ derived from APP and a microtubule associated protein tau [5]. The experimental research in $\mathrm{AD}$ for exploring disease pathogenesis has been dominated by the attempts for identification of various neurotoxic consequences of abnormal protein accumulation on one hand, and on the other by an extensive use of transgenic $\mathrm{AD}$ models harboring single or multiple mutant gene(s) of human familial AD [5, 6, 7, 8]. However, this approach so far has neither explained the complexity and heterogeneity of sporadic human AD, nor produced any reasonably efficacious drug for this condition. It is now increasingly understood that in sporadic AD multiple risk factors from gene- environment interactions working in the backdrop of the aging brain activate and reinforce the disease pathogenesis $[1,2,8]$. The molecular nature of gene-environment interaction or its temporal relationship with the pathogenesis of sporadic $\mathrm{AD}$ is largely unknown. However, one interesting theory, the Latent Early- life Associated Regulation (LEARn) model, has envisaged that exposure to environmental risk factors (e.g. heavy metal exposure, nutritional deficiency etc.) in early developmental life brings about epigenetic modifications of AD related genes (e.g. Amyloid Precursor Protein or APP gene) that remain latent for many years till a second 'hit' (e.g. aging associated elevated pro-inflammatory cytokines, unhealthy mid-life diet etc.) results in sustained alterations in the expressions of these early-affected genes manifesting the full-blown disease $[9,10]$. The epigenetic modifications of $\mathrm{AD}$ related genes affected by the early life exposure to environmental risk factors may include DNA methylation or oxidation or chromatin re-organization $[9,10]$. The novel and attractive LEARn model which advocates the role of environmental risk factors and traces the origin of $\mathrm{AD}$ to early developmental stage, however, needs further support from experimental and epidemiological studies. On the other hand, many AD researchers tend to suggest that the environmental risk factors operate during the preclinical phase of the disease decades before the appearance of clinical dementia. In either way, there is overwhelming support for environmental or extra-genetic risk factors as inducers of $\mathrm{AD}$ pathogenesis. These environmental or extra-genetic risk factors are varied in nature and origin, but for the sake of the present review we may club a few of them as metabolic risk factors and attempt to understand their biological implications in the context of disease pathogenesis and therapeutic strategies (Fig.1). The growing literature of metabolic risk factors of sporadic Alzheimer's disease (AD) extending from epidemiology to molecular pathogenesis and therapeutic management, however, is replete with controversies and contradictions. Nevertheless, this is an active area of research and one that holds enormous promise in the future development of treatment strategies to combat $\mathrm{AD}$ primarily because much of the data are obtained directly from clinical cases. Secondly, the identification of clear metabolic risk factors for AD will give us an opportunity to halt the progress of $\mathrm{AD}$ by dietary manipulation or lifestyle management. The idea of blocking or halting $\mathrm{AD}$ pathogenesis by dietary manipulations (e.g. supplementation with folate and vitamin B12) or life-style changes during the early developmental phase or latent phase of the disease has also been espoused by those proposing the LEARn model of sporadic AD [10, 11]. This review will try to present an overview of $A D$ bringing out the dilemmas and uncertainties of clinical diagnosis, neuropathology and molecular pathogenesis before providing an account of predisposing metabolic risk factors of this disease.

\section{Alzheimer's disease: clinical diagnosis, pathology and molecular pathogenesis.}

\section{Clinical Diagnosis}

The clinical diagnosis of $\mathrm{AD}$ requires thorough history and neuropsychological evaluation following the criteria set by NINCDS/ADRDA (Neurological and Communicative Disorders and Stroke and Alzheimer's Disease and Related Disorders Association) in 1984, which are comparable to those used by other expert bodies e.g. DSM IV (Diagnostic and Statistical Manual of Mental Disorders) [12]. Fundamentally, an insidious onset of progressive dementia with impairment of multiple cognitive domains documented by Mini Mental State Examination or Blessed Dementia Scoring or similar tests usually after 65 years of age is considered as diagnostic of probable $\mathrm{AD}$ in the absence of any other dementia producing systemic illness or neurological disease $[12,13]$. Various mood or behavioral alterations like depression, agitation, apathy, social withdrawal, insomnia, delusion, emotional or physical outburst are also typical characteristics of AD $[12,13]$. The diagnosis can be supported by MRI (magnetic resonance imaging) evidence of diffuse atrophy involving hippocampus and neocortex of the brain. However, the clinical diagnosis is often confused with other forms of dementia like Lewy body dementia, HIV dementia, Huntington's disease, frontotemporal dementia, dementia due to Parkinson's disease and hydrocephalus, Cruetzfeldt-Jacob disease and other conditions [12, 14]. Vascular dementia poses a special problem because of overlapping clinical features and etiopathogenesis $[15,16]$. Thus, in a significant 
number of cases of clinically diagnosed probable $\mathrm{AD}$, the final autopsy report does not confirm the presence of $\mathrm{AD}$ pathology. Over the last two decades, the understanding of the pathogenesis of $\mathrm{AD}$ and other types of dementias at the cellular and molecular level has enormously increased, and coupled with this the PET imaging methods of reduced glucose uptake or increased amyloid beta deposition in AD brain and the identifications of CSF biomarkers of this disease condition have been developed. This has necessitated some modifications of the original diagnostic criteria and introduction of new terminologies and classifications, which could help in identifying the $\mathrm{AD}$ patients with greater degrees of certainty. Thus, as recommended by National Institute of Aging Alzheimer's Association (NIA - AA) workgroups, AD is a continuum of disease process which includes preclinical $\mathrm{AD}$, mild cognitive impairment $(\mathrm{MCI})$ and $\mathrm{AD}$ dementia [17, 18, 19]. AD dementia patients would be further categorized as ' probable $\mathrm{AD}$ ' and 'possible $\mathrm{AD}$ (i.e. AD dementia with an atypical course or with another co-morbidity such as cerebro-vascular disease, Lewy body dementia or any other disease affecting cognition)' on the basis of history and neuropsychological examination, while the diagnosis of 'probable $\mathrm{AD}^{2}$ or 'possible $\mathrm{AD}^{\prime}$ with $\mathrm{AD}$ pathophysiologic process will require CSF biomarker examination (A $\beta 42$, total tau or phosphorylated tau) or PET evidence of decreased ${ }^{18} \mathrm{~F}-2$ deoxyglucose uptake or increased accumulation of amyloid beta peptide in brain [19]. The present recommendations have emphasized that ' probable $\mathrm{AD}^{\text {' or }}$ ' possible AD' diagnosis is sufficient in clinical settings, while for research purposes a more definitive diagnosis of 'probable' or 'possible' AD with AD pathophysiologic process is necessary [19]. Similarly, pre-clinical AD is to be used only for research purposes e.g. for selection of cohorts for longitudinal clinical studies [17]. The inherent uncertainty and ambiguity of AD diagnosis as outlined here is to be kept in mind in the context of our current discussion on $\mathrm{AD}$ and its multiple risk factors, since the former can confound the results of epidemiological studies significantly.

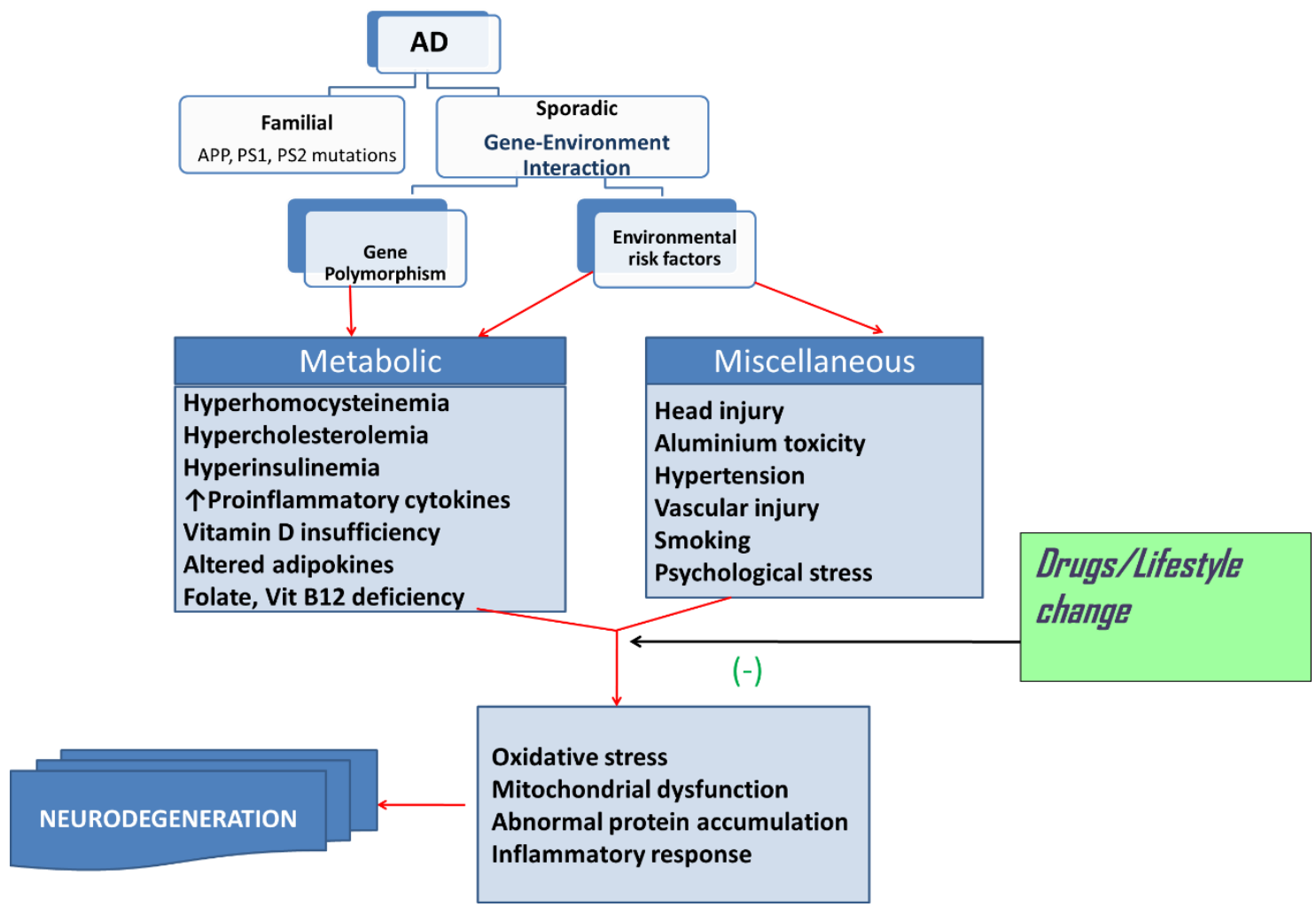

Figure 1. Risk factors of Alzheimer's disease. Gene -environment interactions may be the underlying mechanism of sporadic AD. Environmental risk factors include those present in external environment or extra-genetic internal milieu of the body. The risk factors may affect the functions of AD-related genes or their regulatory regions by methylation, oxidation or other mechanisms. Gene polymorphisms, on the other hand, may aggravate the effects of the risk factors on $\mathrm{AD}$ pathogenesis. Drugs, diet and life-style may prevent the interaction of risk factors with $\mathrm{AD}$ pathogenic mechanisms. 


\section{Neuropathology of $A D$}

The histopathology of AD brain has two hallmarks of extracellular amyloid or senile plaques and neurofibrillary tangles in neuronal perikarya $[20,21,22]$. The amyloid plaques appear in several varieties e.g. neuritic plaques, diffuse amyloid plaques, amyloid lakes, cotton-wool plaques etc. [20]. The neuritic plaques are composed of a core deposit of amyloid beta peptide (predominantly $\mathrm{A} \beta 42$ and $\mathrm{A} \beta 40$, but also several other amyloid peptides of different chain lengths) in different degrees of oligomerization state surrounded by dystrophic neurites $[20,22]$. The neurofibrillary tangles, on the other hand, are composed of paired helical filaments of hyperphosphorylated tau proteins detected by histochemical stains or immuno-histochemistry [20, 22]. The distributions of these typical AD lesions are approximately in the same regions and involve enterorhinal cortex, hippocampus, amygdala and different areas of neocortex [20, 21, 22]. There are other accompaying features of $\mathrm{AD}$ pathology like neuronal loss, degeneration of synapses, dendrites and axons, gliosis, white matter rarefaction, ganulovacuolar degeneration and cerebral amyloid angiopathy [20, 22]. Further, apart from amyloid beta peptides or abnormal tau protein, several other proteins also accumulate in various degrees in AD brain like $\alpha$ - synuclein, TDP-43 (TAR DNA binding protein), actin giving rise to various forms of inclusion bodies like Lewy bodies, Hirano bodies etc. [20, 22]. Since the post-mortem confirmation of AD diagnosis rests on autopsy findings, attempts have been made over the years for systematic and well standardized criteria, qualitative and quantitative, for identifying the neuropathology of AD brain [23, 24, 25]. The NIAREGAN (National Institute of Aging / Regan Institute of the Alzheimer Association) criteria set in 1997 have been revised recently by NIA - AA workgroups and provided guidelines for autopsy reporting of $\mathrm{AD}$ neuropathology irrespective of clinical presentations of the subjects [20, 25]. The present recommendations have outlined the $\mathrm{ABC}$ scoring for describing AD neuropathology: A for amyloid deposit, B for Braak staging of neurofibrillary tangles and $\mathrm{C}$ for neuritic plaques as per CERAD (Consortium to Establish a Registry for Alzheimer's Disease) criteria. By this $\mathrm{ABC}$ scoring, AD neuropathlogy can be graded as 'No', 'Low', 'Intermediate' and 'High', and further NIA AA suggestions include pathological description of all comorbidities e.g. vascular brain injury, hippocampal sclerosis etc. [20, 22].

\section{Clinical AD vs. AD Neuropathology: Ambiguity and} Controversy

It is to be emphasized that the impairment of cognitive domains on which the clinical diagnosis of $\mathrm{AD}$ is based is in most cases but not always correlate well with the extent of post-mortem AD neuropathology [26, 27]. In some cases significant AD neuropathology has been observed after autopsy in aged individuals who were non-demented before death which has been explained by the assumption that neuropathology of AD predates the clinical cognitive deficits by many years $[17,20]$. In other cases cognitive decline is much higher in comparison to existing $\mathrm{AD}$ neuropathology, which implies that other co-morbidities like vascular brain injury or Lewy body disease etc. may have contributed to the dementia in such instances [20, 26]. Alternatively, such discrepancies may mean different degrees of 'brain reserve' or 'cognitive reserve' among the affected individuals [17]. Moreover, this discrepancy between the extent of neuropathology and clinical severity of the disease in many cases may also mean that AD pathology which causes dementia and cognitive impairment is not driven solely by the toxic effects of amyloid plaques or neurofibrillary tangles, but other cellular and molecular damage mechanisms such as oxidative damage or mitochondrial dysfunction or other metabolic alterations may be playing more crucial roles in the genesis of this disease [5,20]. It remains uncertain at this moment whether histopathologic diagnosis of $\mathrm{AD}$ should take in to account the features of molecular damage e.g. accumulation of oxidative damage markers, structural and functional alterations in mitochondria, presence of proinflammatory markers etc. in post-mortem $\mathrm{AD}$ brain to obtain a better correlation of neuropathology and cognitive decline. The incongruity between neuropathology and clinical severity of $\mathrm{AD}$ may also explain, at least partially, the discrepancy often observed between epidemiological studies and autopsy findings with regard to the association of a particular risk factor with AD.

\section{Pathogenesis of Alzheimer's Disease}

The central mechanisms in the pathogenesis of $\mathrm{AD}$ have generally revolved round two themes clearly linked to two hallmark lesions found in brain after autopsy in this disease condition. The first and foremost is the abnormal accumulation of oligomeric $A \beta 42$ or related peptides and their multiple toxic effects on neurons and glia leading to oxidative damage, mitochondrial dysfunction, calcium dysregulation, inflammation and ER stress, which together may set in programmed death of neurons [5, 28]. This is the so called 'Amyloid Cascade Hypothesis'. The formation of amyloid beta peptide (predominantly A 342 ) 
from APP through sequential actions of $\beta$ and $\gamma$ secretases in the amyloidogenic pathway, the intracellular trafficking of APP-A $\beta$ from endoplasmic reticulum through protein secretory pathway to plasma membrane and outside, the degradation of $\mathrm{A} \beta 42$ by neprilysin, insulin degrading enzyme (IDE), endothelin converting enzyme, plasmin etc. and the clearance of $A \beta 42$ from the brain have been the subject of several excellent reviews in the context of $\mathrm{AD}$ pathogenesis [28, 29, 30]. It is conceivable that the increased accumulation of amyloid beta peptides in sporadic AD results from increased expression of APP gene and / or increased processing of the APP gene product in the amyloidogenic pathway by means of $\beta$ and $\gamma$ secretases and / or decreased catabolism and clearance of the peptides from the brain. In case of familial AD, the mutations in APP, PS1 or PS2 gene may lead to similar effects with accumulation of amyloid beta peptides in the brain, and the 'Amyloid Cascade Hypothesis' as the pathogenic mechanism of AD has gained huge support from identification of these familial AD mutation $[29,31]$. The other suggested mechanism in AD pathogenesis emphasizes the neuronal and synaptic dysfunctions caused by the abnormal accumulation of phosphorylated tau protein (tauopathy) [32, 33]. Tau protein acts as a substrate for phosphorylation at multiple sites by several different kinases e.g.GSK-3 $\beta$, Cdk5, PKA, MARK etc. in vitro, but it is not clear which of these kinases are responsible for in vivo phosphorylation of tau in physiological or pathological conditions [33]. Under normal physiological conditions the reversible and transient phosphorylation of tau is involved in many neuronal functions such as axonal transport and neurite outgrowth, but pathological hyperphosphorylation of tau leads to oligomerization and fibrillization and decreased binding to microtubules $[32,33]$. Despite a plethora of evidence from animal models (transgenic and chemical induced), cell based models and post-mortem brain of $\mathrm{AD}$ subjects supporting the 'Amyloid Cascade Hypothesis' or 'tauopathy', it is not fundamentally clear how these alterations of abnormal protein accumulation and aggregation are triggered in the aging brain especially in the case of sporadic AD. The LEARn model mentioned earlier posits that environmental risk factor like heavy metal exposure or nutritional deficiency can bring about epigenetic modifications in the regulatory regions of APP or $\beta$-secretase gene to cause increased production of amyloid beta peptide [9, 10]. In general, it may be surmised that the risk factors tend to affect the expression, processing and trafficking of APP and amyloid beta peptide or change the phosphorylation state of tau proteins through multiple kinases and phosphatases. Furthermore, extensive post-mortem evidence of accumulation of oxidative damage markers of phospholipids (malondialdehyde, 4-hydroxynonenal (4-HNE), $\mathrm{F}_{2}$ isoprostane etc.), protein (protein carbonyls, HNE-protein adducts) and nucleic acids in AD brain is available [34, $35,36]$. Likewise evidence of mitochondrial dysfunction and intramitochondrial accumulation of amyloid beta peptide in $\mathrm{AD}$ brain has been clearly documented in postmortem AD brain $[37,38]$. The inflammatory response by activated microglia and also astrocytes leading to production of cytokines, chemokines and reactive oxygen species (ROS) with associated neuronal damage is another important feature of AD pathogenesis [39, 40]. A growing body of recent evidence has indicated the activation of several types of inflammosomes in microglia, and also possibly in neurons, that drives the inflammatory response and neurodegeneration in $\mathrm{AD}$ brain [41, 42]. It is a moot point whether all these alterations are simply the secondary consequences of abnormal accumulation of amyloid beta peptide or hyperphosphorylated tau in $\mathrm{AD}$ brain or they represent independent damage mechanisms working in concert in the backdrop of an aged brain to bring about neurodegeneration as well as characteristic $\mathrm{AD}$ proteinopathy.

\section{Metabolic and Endocrine Components in AD pathogenesis:}

One of the earliest manifestations of $\mathrm{AD}$ is the decreased cerebral utilization of glucose as evidenced by PET imaging of ${ }^{18} \mathrm{~F}-2$ deoxyglucose uptake in the AD brain, and the phenomenon is progressive with the disease and well correlated with the degree of cognitive decline in $\mathrm{AD}$ brain $[43,44]$. The multiple reasons for cerebral glucose hypometabolism in $\mathrm{AD}$, its relationship with oxidative stress and the use of alternative substrates under such condition have been well reviewed [43, 44]. The metabolic implications of $\mathrm{AD}$ pathogenesis in the context of brain insulin deficiency and insulin resistance have been extensively discussed in several recent publications $[45,46]$. Although multiple causes have been attributed to altered food intake and loss of body weight in $\mathrm{AD}$, the fact also implies a role of hormones like insulin and adipokines in its pathogenesis [48, 49, 50]. The mitochondrial dysfunction and inhibition of key metabolic enzymes involved in energy production like the glycolytic enzymes as also pyruvate dehydrogenase, $\alpha$-ketoglutarate dehydrogenase, cytochrome oxidase are established features of $\mathrm{AD}$ pathology indicating general metabolic perturbation in brain in this condition [50, 51]. The transcriptome data from neurodegenerative and neurological diseases incorporated in brain-specific metabolic network models have indicated alterations in several key metabolites and pathways in AD brain that are related to energy, lipid and ROS metabolism [52]. The role of glucose and lactate metabolism in AD brain has 
been recently analyzed from the proposed alternative view of brain metabolism based on astrocyte-neuron-lactateshuttle [53]. Metabolic syndrome, a condition characterized by multiple biochemical and physiological alterations like hyperglycemia, dyslipidemia, hypertension, obesity etc., has been linked with the genesis of sporadic AD [54]. Thus, there is substantial evidence supporting a strong metabolic component in $\mathrm{AD}$ pathogenesis which calls for a systematic discussion of metabolic risk factors of sporadic AD.

\section{Metabolic Risk Factors of AD: Present Status}

Although in the context of the present discussion, we are primarily concerned with the metabolic risk factors of sporadic $\mathrm{AD}$, it is to be understood that gene polymorphisms associated with sporadic AD may modulate the role of these risk factors in multiple ways in the disease pathogenesis. The polymorphism of APOE is considered as a definite risk factor for $\mathrm{AD}$ with $\varepsilon 4$ allele (APOE4) showing strong association with the disease, but the estimated risk attributable to APOE4 varies in different populations depending on the frequency of this allele in a particular population [55]. The protein coded by $A P O E$ is apolipoprotein $\mathrm{E}$ which is involved in cholesterol transport in the periphery as well as cholesterol trafficking within the brain, and $A P O E$ genotype and serum total cholesterol interaction has been suggested in AD progression [56]. Recent large genomewide association studies have identified several other genetic susceptibility loci for AD which include $C R 1$, SORL 1, PICALM, CLU etc. [57]. Apart from the gene polymorphisms, population based long-term prospective as well as cross-sectional retrospective studies have identified many risk factors of sporadic $\mathrm{AD}$, and some of these like hypercholesterolemia, type 2 diabetes, hyperhomocysteinemia, elevated circulating proinflammatory cytokines, vitamin D deficiency and altered blood levels of adipokines have obvious metabolic connotation. The possible links of these metabolic risk factors with disease pathogenesis are presented in Fig.2.

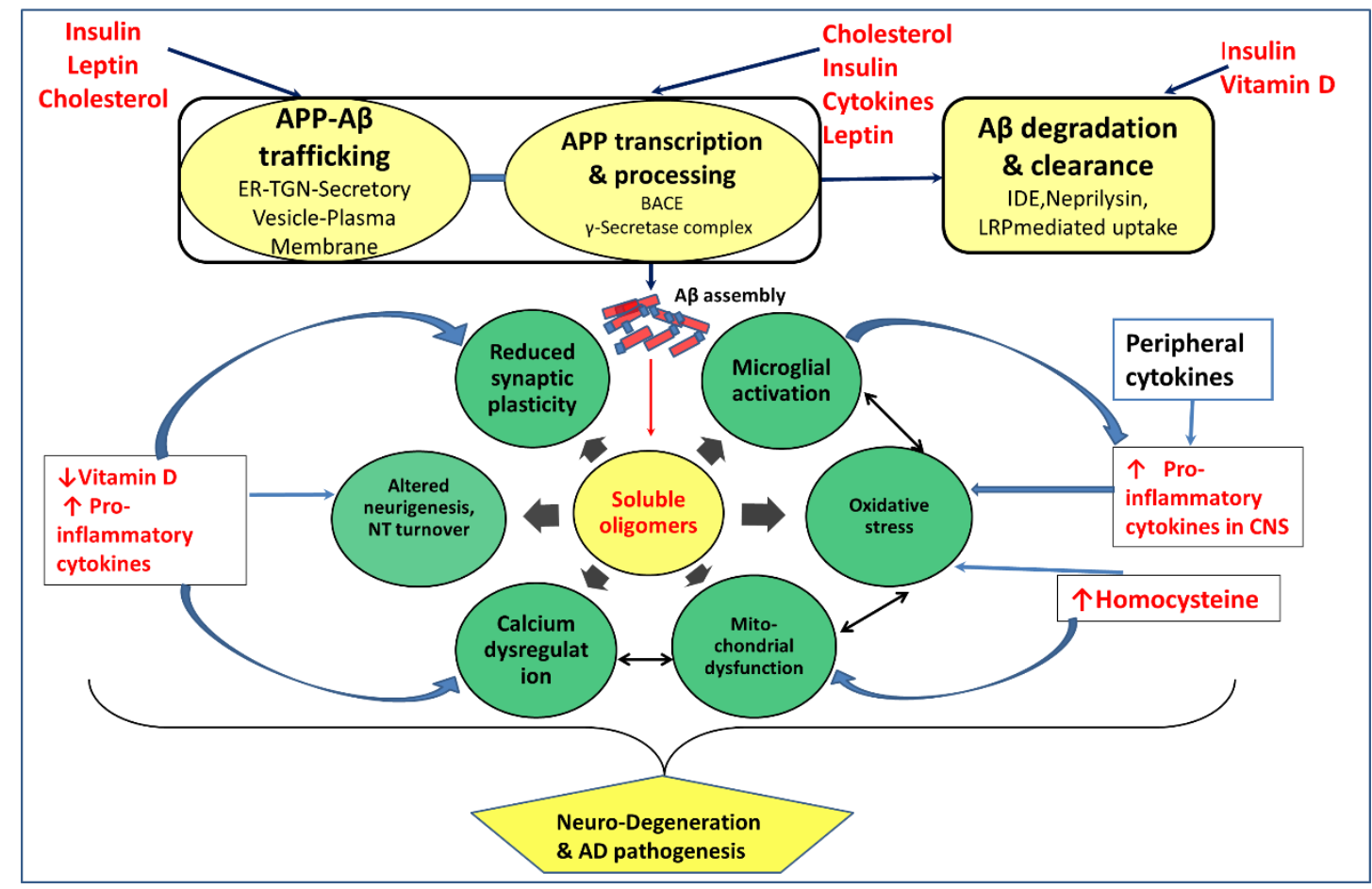

Figure 1. Metabolic risk factors and molecular pathogenesis of AD. AD pathogenesis is represented by interacting damage pathways spearheaded by soluble oligomers of amyloid beta peptide. Altered levels of metabolic risk factors e.g. hormones, vitamins, cytokines, metabolites etc. can affect APP expression and processing or intracellular trafficking, catabolism and clearance of amyloid beta peptide or induce oxidative stress or inflammatory response through interactions at multiple sites leading to neurodegeneration and characteristic proteinopathy of AD. ER-TGN, Endoplasmic reticulum trans- golgi network; BACE, Beta-site APP cleaving enzyme; IDE, Insulin degrading enzyme; LRP, Low density lipoprotein receptor related protein; NT, Neurotransmitter. 


\section{Hypercholesterolemia:}

Large-scale population-based prospective studies have indicated that mid-life hypercholesterolemia is an independent risk factor for $\mathrm{AD}$ even when corrected for age and other confounding factors [58, 59]. Several other prospective studies have also reported that hypercholestolemia is a risk factor for $\mathrm{AD}$ even after adjustment of APOE4 attributed risk [60]. One population based study of African Americans has shown that higher serum cholesterol is associated with increased risk of AD in APOE4 negative subjects, but not in those carrying at least one $\varepsilon 4$ allele [61]. Many case - control studies have also confirmed that mild hypercholesterolemia accompanies late-onset AD [49, 62, 63]. However, a 32year long follow-up study of 1462 women has failed to find an association of mid-life hypercholesterolemia with increasing risk of $\mathrm{AD}$, and even some studies have indicated that a high blood cholesterol especially in latelife is actually protective against $\mathrm{AD}[64,65,66]$. The statin group of cholesterol lowering agents has been shown to produce beneficial effects in $\mathrm{AD}$ subjects in some studies [67]. A recent careful analysis of existing literature has shown that the association of hypercholesterolemia with $\mathrm{AD}$ is quite compelling, but the beneficial effect of statin therapy is not firmly established [68, 69].

In experimental cell based research, cholesterol distribution within membrane is seen to have effects on APP metabolism, trafficking of APP, activities of $\beta, \gamma$ and $\alpha$ secretases and $A \beta$ synthesis $[70,71]$. In transgenic $A D$ mice high cholesterol diet promotes brain amyloidogenesis [72]. The human brain contains a high amount of cholesterol, mostly in the unesterified form, in two pools of which the major one is in myelin and the minor pool in the plasma membranes of glia and neurons $[73,74]$. Since very little cholesterol is transported from the plasma via lipoproteins through the blood-brain barrier, the brain cholesterol is maintained by in situ synthesis and recycling with a small amount moving out from the CSF to the plasma [73, 74]. The recycling and trafficking of cholesterol in the brain requires apoE, lowdensity lipoprotein receptor related protein (LRP) and VLDL receptor, and the details of this complex pathway have been worked out [71, 75]. In the cell membrane cholesterol is associated with special lipid microdomains known as lipid rafts, and because amyloidogenic processing of APP and oligomerization of $\mathrm{A} \beta$ peptide take place within lipid rafts, cholesterol could modulate the latter phenomena [75]. What is not clearly understandable is how hypercholesterolemia can be an important risk factor for $\mathrm{AD}$ when circulating cholesterol containing lipoproteins do not gain entry in to brain in significant amount. However, high serum total cholesterol is an important vascular risk factor and vascular brain injury may confound epidemiological data linking hypercholesterolemia and AD. Alternatively, vascular brain injury and hypoperfusion of brain can initiate and promote brain amyloid pathology as has been suggested earlier [16]. APOE polymorphism is considered as a strong risk factor for sporadic $A D$ in subjects carrying $\varepsilon 4$ allele, and it has been shown in experiments with cultured neurons that apoE4 isoform is less efficient compared to apoE2 or apoE3 in carrying out efflux of cholesterol from the neurons [76]. The latter effect may promote neuronal production of amyloid $\beta$ peptide. The cholesterol/ ApoE isoform interaction in the progression of $\mathrm{AD}$ pathogenesis has also been observed in population based study [77]. Another interesting connection with cholesterol and $\mathrm{AD}$ is through the oxidation product of cholesterol, 24hydroxyhydroxy cholesterol, which is formed exclusively in the brain $[73,78,79]$. This oxysterol can pass through the blood brain barrier and constitutes an efflux pathway of cholesterol from the brain, and thus the plasma level of 24-hydroxycholesterol is an indicator of brain cholesterol turnover [73, 79]. In $\mathrm{AD}$, the plasma level of 24 hydroxycholesterol is increased presumably as a result of neuronal death and membrane cholesterol turnover [78, 79].

\section{Type 2 Diabetes:}

A population based cohort study has estimated the Relative Risk (RR) of 2.27 for men and 1.37 for women relating AD with type 2 diabetes [80]. Large- scale population based prospective studies have shown that type 2 diabetes increases the risk of late-onset $\mathrm{AD}$, and different studies have calculated the RR varying from 1.44 to $1.9[81,82,83,84]$. Another population based follow up study showed that hyperinsulinemia or type 2 diabetes increases the risk of of $\mathrm{AD}$ with a hazard ratio of 2.2 [85]. A mean follow-up study of 5.5 years for a population of 1138 persons has shown that diabetes is a strong risk factor for $\mathrm{AD}$ (hazard ratio 2.4) and the risk is further augmented when other risk factors like hypertension, heart disease and smoking are simultaneously present [86]. Several meta-analysis studies from published literature have estimated an aggregated relative risk of approximately 1.5 linking type 2 diabetes with $\mathrm{AD}$, and the relative risk increases considerably by the presence of hypertension, smoking and APOE4 positivity [87, 88, 89, 90]. A population based cross-sectional study has also shown the significant association of hyperglycemia and hyperinsulinemia with $\mathrm{AD}$ independent of APOE4 status [91]. However, many epidemiological studies have linked type 2 diabetes more with vascular dementia than $\mathrm{AD}$, and cognitive decline as a consequence of type 2 diabetes per 
se is also well documented [92, 93, 94]. On the other hand, there is a clear discrepancy between epidemiological results and neuropathological autopsy findings in linking $\mathrm{AD}$ with type 2 diabetes. Neuropathological autopsy studies do not support that type 2 diabetes predisposes to development of $\mathrm{AD}$ pathology in the brain of aged persons when compared to age-matched controls [95]. Several epidemiological studies also have examined a proportion of their study cohorts at autopsy for neuropathological changes typical of $\mathrm{AD}$ and concluded that type 2 diabetes does not promote $\mathrm{AD}$ pathology in the brain and instead vascular pathologies in brain are more commonly associated with type 2 diabetes $[89,96]$.

While the controversy is persisting between epidemiological findings and neuropathological observations in relating type 2 with $\mathrm{AD}$, in experimental $\mathrm{AD}$ research insulin and insulin resistance have been linked to $\mathrm{AD}$ pathogenesis in multiple ways. In the brain insulin and IGF signaling regulates a broad range of functions such as glucose and energy metabolism, growth, differentiation, migration, survival and plasticity of neurons [97, 98]. In particular in the context of amyloid beta metabolism, insulin stimulates APP-A $\beta$ trafficking from trans-golgi network to plasma membrane and the extra-cellular release of $A \beta$, and insulin resistance in mice induced by high fat diet causes increased activities of $\beta$ and $\gamma$ secretases with accumulation of amyloid beta peptide $[45,99,100]$. Likewise in $\mathrm{db} / \mathrm{db}$ mice brain or in insulin resistant cultured cells of neural origin, an accumulation of autophagosomes and amyloid beta peptide has been noticed [100]. In addition, insulin competes with $A \beta$ for degradation by IDE (insulindegrading enzyme) and thus may promote $A \beta$ accumulation in the brain in hyperinsulinemic condition, although the evidence suggests that the peripheral hyperinsulinemia of type 2 diabetes actually causes a decreased entry of insulin into brain [101]. The role of insulin in tau phosphorylation has also been explored in different experimental models, and it is suggested that insulin resistance through impaired PI3/Akt signaling may lead to activation of GSK-3 $\beta$ and increased phosphorylation of tau [101, 102].

It has been envisaged that Alzheimer's disease may be a type of 'brain diabetes' or 'type 3 diabetes' resulting from both insulin deficiency and insulin resistance in the brain $[46,84,101]$. This is supported by a body of evidence such as the decreased level of insulin, insulin mRNA and insulin receptor protein in brain, de-sensitization of insulin receptor and decreased levels and impaired functioning of downstream components of insulin signaling pathway in AD brain $[46,103,104,105,106$, 107]. Although the reasons for brain insulin deficiency or resistance in $\mathrm{AD}$ are not clear, it is worthwhile to state in this context that $\mathrm{A} \beta$ oligomers which accumulate in $\mathrm{AD}$ brain as a primary pathologic process can bind to brain insulin receptors and induce the re-distribution of the receptors from the membrane to the cytosol leading to impaired insulin signaling [98]. Likewise, A $\beta$ oligomers can abnormally activate TNF- $\alpha / J N K$ pathway causing phosphorylation of serine residues of IRS-1 and blocking insulin signaling downstream [98]. Whatever may be the mechanism, insulin deficiency and resistance of 'type 3' diabetes can directly contribute to the genesis of $\mathrm{AD}$ pathology in the brain as a primary process by enhancing $A \beta$ accumulation and tau phosphorylation. In conformity with this idea of brain insulin deficiency and resistance in $\mathrm{AD}$, intracerebro-ventricular administration of streptozotocin in mice causes $\mathrm{AD}$ like neuropathology and cognitive deficits [46, 108]. However, this proposition of $\mathrm{AD}$ per se as a case of 'brain diabetes', though attractive, needs further scrutiny, and rather it may be more logical to think that insulin deficiency and resistance is conferred on $\mathrm{AD}$ brain secondarily by coexisting peripheral insulin resistance diseases like type 2 diabetes. In turn, the brain insulin resistance aggravates the $\mathrm{AD}$ pathologic process presumably by altering APP expression, processing, trafficking and degradation and / or phosphorylation of tau or by causing metabolic perturbations, oxidative stress and mitochondrial dysfunctions through inter-dependent pathways. The possibility that co-existing type 2 diabetes accelerates $\mathrm{AD}$ pathogenesis is not only supported by epidemiological evidence, but also by studies in transgenic Tg2576 AD mice in which dietary high fat induced insulin resistance promotes $\mathrm{A} \beta$ peptide generation and amyloid plaque formation in the brain [109]. Another recent study has shown that cross-mating of ob/ob or NSY diabetic mice models with APP transgenic mice results in double transgenic animals in which both $\mathrm{AD}$ and type 2 diabetes pathologies are aggravated [110]. Although acute infusion of insulin in peripheral circulation tends to raise CSF insulin, in type 2 diabetes, chronic hyperglycemia and hyperinsulinemia lead to decreased entry of insulin in to brain resulting in lower CSF and brain insulin levels and a state of brain insulin deficiency [101, 111, 112]. Thus both insulin deficiency and insulin resistance would be present in $\mathrm{AD}$ brain as a result of co-existing type 2 diabetes. However, the molecular defect that generates insulin resistance in type 2 diabetes is neither precisely known, nor it is known whether the mechanism of insulin resistance is the same for all tissues like skeletal muscles, adipose tissue or liver. Thus, it will be an interesting area of exploration to elucidate the mechanism of brain insulin resistance in type 2 diabetes and its consequence on the co-existing AD pathology. A corollary of this complex interaction of type 2 diabetes and $\mathrm{AD}$ is the possibility of a beneficial effect of insulin or insulin-sensitizers in 
blocking the genesis and progression of sporadic $\mathrm{AD}$, but the results are still not unequivocal in this respect [103, $113,114]$.

\section{Hyperhomocysteinemia}

Hyperhomocysteinemia has been well recognized as a cardiovascular risk factor from epidemiological and experimental studies [115]. The causes of hyperhomocysteinemia in general population are multiple and include both genetic and non-genetic mechanisms. The mutations of genes coding for major enzymes involved in homocysteine remethylation or transulfuration pathways e.g. cystathionine $\beta$ synthase, methionine synthase, methylene tetrahydrofolate reductase etc. can lead to hyperhomocysteinemia [116]. The deficiency of vitamin cofactors of homocysteine metabolism like vitamin B12, folate and pyridoxine may also be responsible for hyperhomocysteinemia in general population [116].

Many case-control as well as prospective studies have associated high plasma homocysteine with $\mathrm{AD}$ which has been well reviewed in a recent publication [117]. Several large -scale long follow-up studies have demonstrated an increased risk of $\mathrm{AD}$ with high plasma total homocysteine after adjustment of other variables [118, 119]. In the Framingham Offspring Study, 2096 participants have been examined seven times for multiple parameters for 30 years followed by a battery of neuropsychological tests, and an inverse association of plasma total homocysteine with multiple cognitive domains has been noted in subjects above 60 years or above [120]. A recent meta-analysis of eight cohort studies has also confirmed the association of hyperhomocysteinemia with increased risk of $\mathrm{AD}$ with an odds ratio of 1.35 for every $5 \mu \mathrm{mol} / \mathrm{L}$ increase in plasma homocysteine [121]. Many epidemiological studies have simultaneously measured plasma total homocysteine, folate, vitamin B12, vitamin B6 in cohorts in relation to $\mathrm{AD}$ risk and established that hyperhomocysteinemia is associated with deficiency of these vitamins $[118,122$, $123,124,125]$. There has been a general optimism that corrections of hyperhomocysteinemia by supplementation with folate, vitaminB12 and vitamin B6 would be beneficial in preventing or halting AD progression [126]. However, several interventional epidemiological studies have shown that while hyperhomocysteinemia can be reversed by supplementation with vitamin B12, folate, pyridoxine etc., the dementia is not improved [127, 128]. Since homocysteine is a known vascular risk factor, it is likely that hyperhomocysteinemia probably contributes to vascular component of AD pathology. Several casecontrol studies have shown that the degree of hyperhomocysteinemia is more in typical vascular dementia than in $\mathrm{AD}[129,130]$. Nevertheless, many experimental studies have shown that homocysteine in higher than physiological concentrations can induce a wide range of neurotoxic effects involving oxidative stress, excitotoxicity, mitochondrial dysfunction, DNA damage and apoptosis implying that hyperhomocysteinemia may directly contribute to $\mathrm{AD}$ neurodegeneration $[117,131,132,133]$.

\section{Adipokines}

The fact that $\mathrm{AD}$ is accompanied by significant metabolic changes in the brain and altered food intake and body weight, some significant studies, epidemiological and experimental, have been made on the role of adipokines like leptin and adiponectin in $\mathrm{AD}$. Adiponectin regulates glucose, lipid and energy metabolism and insulin sensitivity in many tissues through AdipoR1 and AdipoR2 receptors using complex signaling mechanisms involving AMPK, p3-MAPK, PPAR- $\alpha$ and NF-k $\beta$ [134, $135,136]$. The role of adiponectin in regulating brain metabolism and function is less established, but the globular, trimeric and hexameric forms of the hormone are believed to cross the blood-brain barrier and act on receptors present in different brain areas [137]. Under physiological conditions, adiponectin may be responsible for regulation of energy metabolism of the brain and control of food intake [137]. The other important adipokine, leptin, acts through $\mathrm{Ob}-\mathrm{Rb}$ (the long form of the receptor) utilizing an array of downstream signaling mechanisms e.g. Jak-Stat, Erk, PI3K/Akt and AMPK $[138,139]$ Leptin is known to affect satiety, food intake and body weight through its action in hypothalamus, but the hormone has more diverse neurotrophic and neuroprotective actions in the brain and also affects hippocampal neurigenesis and long-term potentiation $[138,139,140]$. Several case-control and large population based prospective studies have shown an inverse association of circulating leptin levels with $\mathrm{AD}$ or general cognitive decline [141, 142, 143]. In case of adiponectin the epidemiological link with AD risk is less clear. Some case-control and large follow-up studies have shown an association of higher circulating level of adiponectin with increased risk of $\mathrm{AD}$, but others have not replicated these findings $[144,145,146]$. A recent case-control study has measured the serum levels of adiponectin and leptin in the same cohorts of $\mathrm{AD}$ and confirmed a raised level of adiponectin and a lower leptin level in serum of $\mathrm{AD}$ subjects which are in good correlation with the severity of the disease as measured by MMSE scores [49]. Extensive experimental studies in cell lines and AD transgenic mice have indicated that leptin can affect APP-A $\beta$ trafficking, $\mathrm{A} \beta$ accumulation and clearance, $\beta$ secretase expression as also phosphorylation of tau protein [139, 140, 147]. 
Adiponectin on the other hand may have a proinflammatory role in AD brain [137].

\section{Proinflammatory cytokines}

The AD brain elicits a strong inflammatory response primarily by activated microglia and to a lesser extent by astrocytes. The microglia during inflammatory response show typical morphological changes with expression of specific surface markers and release of proinflammatory interleukins, interferons, chemokines and reactive oxygen species $[39,40,148,149]$. On the other hand, as part of this inflammatory response, an alternative activation of microglia and acquired deactivation take place which helps in repair, resolution and neuroprotection [149]. In $\mathrm{AD}$ brain the activation of the microglia is triggered by oligomeric amyloid beta peptide and amyloid fibrils and the resulting pro- inflammatory response mediated by IL1, IL- 6 and TNF- $\alpha$, complement system, chemokines etc. plays an important role in neurodegeneration of $\mathrm{AD}$, while anti-inflammatory cytokines IL-4, IL-10 and TGF- $\beta$ also liberated from the microglia may assist in neuroprotection $[40,148,150,151,152]$. The role of pro-inflammatory cytokines in $\mathrm{AD}$ pathogenesis has recently gained some intense attention because of the evidence suggesting the activation of the inflammosome, NLRP3, in the brain of transgenic $\mathrm{AD}$ mice and patients of mild cognitive impairment and AD dementia [153, 154]. The inflammosomes, the intracellular multi-protein complexes consisting of nucleotide binding oligomerization domain (NOD)- like receptor proteins (NLRP), adaptor proteins and downstream effector proteins, become activated by a wide array of pathogen and danger related molecular patterns through NLRP [42, 154]. There are several types of inflammosomes, but the microglial NLRP3 which is coupled to ASC (apoptosis associated spec-like protein containing caspase recruitment domain) and caspase 1 probably plays a key role in $\mathrm{AD}$ pathogenesis $[42,154]$. The phagocytosed fibrillar amyloid beta peptide within microglia activates NLRP3 through lysosomal degradation leading to activation of caspase 1 that induces maturation and secretion of pro-inflammatory cytokines IL- $1 \beta$ and IL-18 $[41,154]$. However, independent of the brain immune response, raised levels of circulating proinflammatory cytokines have been generally reported in AD subjects in both longitudinal as well as case-control studies, though significant variability has also been noted $[155,156,157$, 158]. A systematic meta-analysis of published reports has clearly shown that raised serum levels of IL-6, TNF- $\alpha$ and IL-1 are associated with increased risk of AD [159]. Some studies have measured serum and CSF levels of cytokines simultaneously in AD subjects, but generally serum level is not reflective of that of CSF [159]. A recent case- control study of a relatively small sample size has suggested that raised levels of proinflammatory cytokines like IL-6, IL- $1 \beta$ and TNF- $\alpha$ are present only in AD patients with associated depression [160]. The communication pathways between the peripheral immune system and the CNS have been identified in details which include both humoral and neural mechanisms, and through this the raised levels of peripheral proinflammatory cytokines can increase the CNS production of cytokines which have varied actions in CNS through widely distributed receptors [161, 162]. The cytokines have neuromodulatory and neurotrophic actions and can also affect neurigenesis, synaptic plasticity, synaptic scaling, neurotrasmitter turnover and the activity of hypothalamus-pituitary axis $[162,163]$. Thus, the activation of peripheral immune system during systemic infection or after systemic injection of lipopolysaccharides or endotoxins or interleukins can cause behavioral and cognitive alterations in animals and human beings $[164,165,166]$. Additionally, this mechanism may be causal to many psychiatric and neurological diseases $[148,167,168]$. In the context of $\mathrm{AD}$ pathogenesis, the central pro-inflammatory cytokines have been shown to enhance the phosphorylation of tau or production of amyloid beta peptide and potentiate the neurodegeneration process $[148,169,170]$.

\section{Vitamin D}

Vitamin $\mathrm{D}_{3}$ synthesized from 7-dehydrocholesterol in the epidermis by photochemical reaction is sequentially hydroxylated in liver and kidney by cytochrome P450 dependent enzymes to produce 1,25 dihydroxy vitamin $D_{3}$, the active form of vitamin $D_{3}$, which acts as a hormone producing diverse effects in tissues apart from its classical role in $\mathrm{Ca}^{2+}$ and phosphate metabolism [171]. The serum level of vitamin $\mathrm{D}_{3}$ is typically monitored by measuring 25-hydroxy vitamin $\mathrm{D}_{3}$. Vitamin $\mathrm{D}$ has both genomic and non-genomic actions mediated by nuclear and membrane receptors respectively, and the receptor VDR is identical in both the locations [171, 172]. The nuclear VDR heterodimerizes with retinoid $\mathrm{X}$ receptor and in concert with several coactivators regulates the transcription of a wide variety of genes in different tissues [171, 172]. In CNS development, vitamin D helps in neuronal differentiation and axonal growth, and in the adult brain it regulates the synthesis of neurotrophic factors and neurotransmitters and also exhibits neuroprotective and antioxidative functions [173, 174, 175].

The association of VDR polymorphism with increased risk of $\mathrm{AD}$ has been shown in several studies. The polymorphism in intron 8 recognized by ApaI, but not one recognized by TaqI in exon 9, is associated with increased risk of $\mathrm{AD}$ [176]. Another promoter SNP 
(single-nucleotide polymorphism) corresponding to the transcription factor $\mathrm{Cdx}-2$ binding region of VDR gene has also been linked to increased risk of $\mathrm{AD}$ [177]. Haplotype analysis of 5 polymorphic sites has shown that the frequency of TaubF haplotype (alleles of TaqI, ApaI, Tru9I, BsmI, FokI) is significantly higher in AD patients [178]. Several observational case-control studies have indicated that the deficiency of plasma 25-hydroxy vitamin $\mathrm{D}_{3}$ is associated with cognitive decline in elderly or with $\mathrm{AD}[179,180]$. A large population based prospective studies of Danish subjects over a follow up period of 30 years has concluded that 25-hydroxy vitamin D3 deficiency increases the risk of AD [181]. Other studies have shown that plasma vitamin $\mathrm{D}$ is an important determinant of cognitive status, CSF A $\beta 42$ level and brain volume in patients of $\mathrm{AD}, \mathrm{MCI}$ and subjective cognitive impairment [182].

In cell based experiments, vitamin $\mathrm{D}$ has been shown to inhibit $A \beta$ induced cytotoxicity and apoptosis in cultured cortical neurons [183]. In post-mortem AD brain, a decreased level of VDR mRNA has been reported in hippocampal region [184]. 1, 25 dihydroxy vitamin D has been shown to increase the clearance of $A \beta$ peptide from mouse brain [185]. In neuroblastoma cells, VDR overexpression or vitamin D treatment increases APP transcription [177]. The macrophages from AD subjects show decreased phagocytosis of soluble $A \beta$, and thus delay the clearance of amyloid beta load of the brain [186]. 1, 25, dihydroxy vitamin $\mathrm{D}_{3}$ alone or in combination with curcuminoids can strongly activate the macrophages from $A D$ subjects to remove $A \beta$ by phagocytosis [186]. A vitamin D3-enriched diet has been shown to decrease the amyloid plaque load and inflammatory reaction and increase NGF production in the brain of $\mathrm{AD}$ transgenic mice [187]. It appears plausible that vitamin $\mathrm{D}$, because of its diverse genomic and non-genomic effects in CNS, will impact amyloid pathogenesis at multiple levels.

\section{Metabolic Risk Factors of AD: Future Possibilities}

Epidemiological studies as mentioned here have identified several important metabolic risk factors having moderate to strong association with $\mathrm{AD}$, but these reports also exhibit extreme variability in many cases. Moreover, neuropathological autopsy studies in large cohorts have often not supported the epidemiological data. The experimental studies have also not convincingly elucidated the pathways that could link these risk factors to the disease pathogenesis. Much of this confusion has arisen from the inherent uncertainty of $\mathrm{AD}$ diagnosis, absence of simple and specific biomarkers for disease identification, ambiguity in neuropathology, incomplete understanding of pathogenesis and frequent absence of correlation between clinical severity and the extent of neuropathology. Thus, the effectiveness of risk factor modification by drugs (e.g. statins, B vitamins, vitamin D, insulin or other anti-diabetic agents and anti-depressants) or life-style management to halt the progression of AD has not been firmly established. However, this is a possibility with significant optimism because of the scarcity of effective drugs for the treatment of $\mathrm{AD}$, the recent major failure of anti-amyloid therapeutics in clinical trials and uncertain effectiveness of potential disease-modifying agents [188, 189]. Another important issue should also be addressed at this point with regard to experimental models used for $\mathrm{AD}$ research. There is no proper animal model for sporadic $\mathrm{AD}$, but an overwhelming emphasis has been given on transgenic AD models to understand the disease pathogenesis. It is intuitively illogical to assume that the pathogenesis of sporadic AD which occurs without any definite mutation would be explained by a transgenic model harboring single or multiple mutations. The clear identification of metabolic risk factors may help us to develop a disease model that would truly simulate sporadic AD pathogenesis.

\section{Acknowledgement:}

We thank the Department of Biotechnology, Govt. of India, New Delhi for the financial support to our research on Alzheimer's disease. We also thank 'The West Bengal University of Health Sciences' for their help and encouragement.

\section{Conflicts of Interest:}

The authors declare no conflict of interest.

\section{References:}

[1] Reitz C, Brayne C, Mayeux R (2011). Epidemiology of Alzheimer disease, Nat Rev Neurol, 7:137-152.

[2] Duthey B (2013). Background Paper 6.11. Alzheimer Disease and other Dementias. 6.11:4-74.

[3] van der Flier WM, Scheltens P (2005). Epidemiology and risk factors of dementia, $\mathrm{J}$ Neurol Neurosurg Psychiatry, 76:v2-7.

[4] Bird TD (2012). Early-onset familial Alzheimer disease. In:Pagon RA, Adam MP, Ardinger HH, Bird TD, Dolan CR, Fong CT, Smith RJH, Stephens K, editors. GeneReviews. Seattle: NCBI, 1-17.

[5] Swerdlow RH (2007). Pathogenesis of Alzheimer's disease. Clin Interv Aging. 2:347-359.

[6] Armstrong RA (2011). The pathogenesis of Alzheimer's disease: a reevaluation of the "amyloid cascade hypothesis". Int J Alzheimers Dis, 2011:630865.

[7] Elder GA, Gama Sosa MA, De Gasperi R (2010). Transgenic mouse models of Alzheimer's disease. Mt Sinai J Med, 77:69-81. 
[8] Mattson MP (2004). Pathways towards and away from Alzheimer's Disease. Nature, 430:631-639.

[9] Lahiri DK, Maloney B, Zawia NH (2009). The LEARn model: an epigenetic explanation for idiopathic neurobiological diseases. Mol Psychiatry, 14:992-1003.

[10] Lahiri DK, Maloney B, Basha MR, Ge YW, Zawia NH (2007). How and when environmental agents and dietary factors affect the course of Alzheimer's disease: the "LEARn" model (latent early-life associated regulation) may explain the triggering of AD. Curr Alzheimer Res, 4:219-228.

[11] Lahiri DK, Maloney B (2010). The "LEARn" (Latent Early-life Associated Regulation) model integrates environmental risk factors and the developmental basis of Alzheimer's disease, and proposes remedial steps. Exp Gerontol, 45:291-296.

[12] McKhann G, Drachman D, Folstein M, Katzman R, Price D, Stadlan EM (1984). Clinical diagnosis of Alzheimer's disease: report of the NINCDS-ADRDA Work Group under the auspices of Department of Health and Human Services Task Force on Alzheimer's Disease. Neurology, 34:939-944.

[13] Forstl H, Kurz A (1999).Clinical features of Alzheimer's disease. Eur Arch Psychiatry Clin Neurosci, 249:288290.

[14] Geldmacher DS, Whitehouse Jr. PJ (1997). Differential diagnosis of Alzheimers disease. Neurology, 48 Suppl 6: 2S-9S.

[15] Pimmentel EML (2009). Role of neuropsychological assessment in the differential diagnosis of Alzheimer's disease and vascular dementia. Dement Neuropsychol, 3:214-221.

[16] de la Torre JC (2002).Alzheimer disease as a vascular disorder: nosological evidence. Stroke, 33:1152-1162.

[17] Sperling RA, Aisen PS, Beckett LA, Bennett DA, Craft S, Fagan AM et al. (2011). Toward defining the preclinical stages of Alzheimer's disease: recommendations from the National Institute on AgingAlzheimer's association workgroups on diagnostic guidelines for Alzheimer's disease. Alzheimers Dement, 7:280-292.

[18] Albert MS, DeKosky ST, Dickson D, Dubois B, Feldman HH, Fox NC, et al. (2011). The diagnosis of mild cognitive impairment due to Alzheimer's disease: recommendations from the National Institute on AgingAlzheimer's Association workgroups on diagnostic guidelines for Alzheimer's disease. Alzheimers Dement, 7:270-279.

[19] McKhann GM, Knopman DS, Chertkow H, Hyman BT, Jack CR Jr, Kawas CH et al.(2011).The diagnosis of dementia due to Alzheimer's disease: recommendations from the National Institute on Aging-Alzheimer's Association workgroups on diagnostic guidelines for Alzheimer's disease. Alzheimers Dement, 7:263-269.

[20] Hyman BT, Phelps CH, Beach TG, Bigio EH, Cairns NJ, Carrillo MC et al.(2012).National Institute on AgingAlzheimer's Association guidelines for the neuropathologic assessment of Alzheimer's disease. Alzheimers Dement., 8:1-13.
[21] Serrano-Pozo A, Frosch MP, Masliah E, Hyman BT (2011). Neuropathological alterations in Alzheimer disease. Cold Spring Harb Perspect, 1:a006189.

[22] Montine TJ, Phelps CH, Beach TG, Bigio EH, Cairns NJ, Dickson DW, et al. (2012). National Institute on AgingAlzheimer's Association guidelines for the neuropathologic assessment of Alzheimer's disease: a practical approach. Acta Neuropathol, 123:1-11.

[23] Khachaturian ZS (1985). Diagnosis of Alzheimer's Disease. Arch Neurol, 42: 1097-1105.

[24] Joachim CL, Morris JH, Selkoe DJ (1988). Clinically diagnosed Alzheimer's disease: autopsy results in 150 cases. Ann Neurol, 24:50-56.

[25] Hyman BT, Trojanowski JQ (1997). Editorial on Consensus Recommendations for the post-mortem Diagnosis of Alzheimer Disease from the National Institute on Aging and the Reagan Institute Working Group on Diagnostic Criteria for the neuropathological assessment of Alzheimer Disease. J Neuropathol Exp Neurol, 56:1095-1097.

[26] Serrano-Pozo A, Qian J, Monsell SE, Frosch MP, Betensky RA, Hyman BT (2013). Examination of the clinicopathologic continuum of Alzheimer disease in the autopsy cohort of the National Alzheimer Coordinating Center. J Neuropathol Exp Neurol, 72: 1182-1192.

[27] Nelson PT, Alafuzoff I, Bigio EH, Bouras C, Braak H, Cairns NJ, et al. (2012). Correlation of Alzheimer disease neuropathologic changes with cognitive status: a review of the literature. J Neuropathol Exp Neurol, 71:362-381.

[28] Dong S, Duan Y, Hu Y, Zhao Z (2012). Advances in the pathogenesis of Alzheimer's disease: a re-evaluation of amyloid cascade hypothesis. Transl Neurodegener, 1:118.

[29] Haass C, Kaether C, Thinakaran G, Sisodia S (2012). Trafficking and proteolytic processing of APP. Cold Spring Harb Perspect Med, 2:a006270.

[30] Suh YH, Checler F (2002). Amyloid precursor protein, presenilins, and alpha-synuclein: molecular pathogenesis and pharmacological applications in Alzheimer's disease. Pharmacol Rev, 54:469-525.

[31] Bali J, Gheinani AH, Zurbriggen S, Rajendran L (2012). Role of genes linked to sporadic Alzheimer's disease risk in the production of $\beta$-amyloid peptides. Proc Natl Acad Sci USA, 109:15307-15311.

[32] Iqbal K, Liu F, Gong CX, Grundke-Iqbal I (2010). Tau in Alzheimer disease and related tauopathies. Curr Alzheimer Res, 7:656-664.

[33] Johnson GV, Stoothoff WH (2004).Tau phosphorylation in neuronal cell function and dysfunction. J Cell Sci, 117:5721-5729.

[34] Butterfield DA, Perluigi M, Sultana R (2006). Oxidative stress in Alzheimer's disease brain: new insights from redox proteomics. Eur J Pharmacol, 545:39-50.

[35] Zhao Y, Zhao B (2013). Oxidative stress and the pathogenesis of Alzheimer's disease. Oxid Med Cell Longev, 2013:316523.

[36] Chakrabarti S, Sinha M, Thakurta IG, Banerjee P, Chattopadhyay M (2013). Oxidative stress and amyloid beta toxicity in Alzheimer's disease: intervention in a 
complex relationship by antioxidants. Curr Med Chem, 20: 4648-4664.

[37] Santos RX, Correia SC, Wang X, Perry G, Smith MA, Moreira PI, et al. (2010). A synergistic dysfunction of mitochondrial fission/fusion dynamics and mitophagy in Alzheimer's disease. J Alzheimers Dis, 20: S401-S412.

[38] Devi L, Prabhu BM, Galati DF, Avadhani NG, Anandatheerthavarada HK (2010). Accumulation of amyloid precursor protein in the mitochondrial import channels of human Alzheimer's disease brain is associated with mitochondrial dysfunction. J Neurosci, 26:9057-9068.

[39] Zotova E, Nicoll JA, Kalaria R, Holmes C, Boche D (2010). Inflammation in Alzheimer's disease: relevance to pathogenesis and therapy. Alzheimers Res Ther, 2:1.

[40] Wyss-Coray T, Rogers J (2012). Inflammation in Alzheimer disease-a brief review of the basic science and clinical literature. Cold Spring Harb Perspect Med, 2:a006346.

[41] Salminen A, Ojala J, Suuronen T, Kaarniranta K, Kauppinen A (2008). Amyloid-beta oligomers set fire to inflammasomes and induce Alzheimer's pathology. J Cell Mol Med, 12:2255-2262.

[42] Liu L, Chan C (2014). The role of inflammasome in Alzheimer's disease. Ageing Res Rev, 15:6-15.

[43] Mosconi L, Pupi A, De Leon MJ (2008). Brain glucose hypometabolism and oxidative stress in preclinical Alzheimer's disease. Ann N Y Acad Sci, 1147:180-195.

[44] Mamelak M (2012). Sporadic Alzheimer's disease: the starving brain. J Alzheimers Dis, 31:459-474.

[45] Erol A (2008). An integrated and unifying hypothesis for the metabolic basis of sporadic Alzheimer's disease. J Alzheimers Dis, 13:241-253.

[46] de la Monte SM, Tong M (2014). Brain metabolic dysfunction at the core of Alzheimer's disease. Biochem Pharmacol, 88:548-559.

[47] Besser LM, Gill DP, Monsell SE, Brenowitz W, Meranus DH, Kukull W, et al. (2014). Body mass index, weight change, and clinical progression in mild cognitive impairment and Alzheimer disease. Alzheimer Dis Assoc Disord, 28:36-43.

[48] Gillette-Guyonnet S, Nourhashemi F, Andrieu S, de Glisezinski I, Ousset PJ, Riviere D, et al. (2000). Am J Clin Nutr, 71:637S-642S.

[49] Khemka VK, Bagchi D, Bandyopadhyay K, Bir A, Chattopadhyay M, Biswas A, et al. (2014). Altered serum levels of adipokines and insulin in probable Alzheimer's disease. J Alzheimers Dis, 41:525-533.

[50] Cunnane S, Nugent S, Roy M, Courchesne-Loyer A, Croteau E, Tremblay S, et al. (2011). Brain fuel metabolism, aging, and Alzheimer's disease. Nutrition, 27:3-20.

[51] Gibson GE1, Sheu KF, Blass JP (1998). Abnormalities of mitochondrial enzymes in Alzheimer disease. J Neural Transm, 105:855-870.

[52] Mustafa S, Kutlu U, Tunahan Ç (2014). Systematic analysis of transcription-level effects of neurodegenerative diseases on human brain metabolism by a newly reconstructed brain-specific metabolic network. FEBS Open Bio, In press.
[53] Newington JT, Harris RA, Cumming RC (2013). Reevaluating metabolism in Alzheimer's disease from the perspective of the astrocyte-neuron lactate shuttle model. J Neurodeg Dis, 2013: 234572.

[54] Frisardi V, Solfrizzi V, Seripa D, Capurso C, Santamato A, Sancarlo D (2010). Metabolic-cognitive syndrome: a cross-talk between metabolic syndrome and Alzheimer's disease. Ageing Res Rev, 9:399-417.

[55] Crean S, Ward A, Mercaldi CJ, Collins JM, Cook MN, Baker NL, et al. (2011). Apolipoprotein E $\varepsilon 4$ prevalence in Alzheimer's disease patients varies across global populations: a systematic literature review and metaanalysis. Dement Geriatr Cogn Disord, 31:20-30.

[56] 56. Evans RM, Hui S, Perkins A, Lahiri DK, Poirier J and Farlow MR (2004). Cholesterol and APOE genotype interact to influence Alzheimer disease progression. Neurology, 62:1869-1871.

[57] 57. Kamboh MI, Demirci FY, Wang X, Minster RL, Carrasquillo MM, Pankratz VS, et al. (2012). Genomewide association study of Alzheimer's disease. Transl Psychiatry, 2:e117.

[58] 58. Kivipelto M, Helkala EL, Laakso MP, Hanninen T, Hallikainen M, Alhainen K, et al. (2001). Midlife vascular risk factors and Alzheimer's disease in later life: longitudinal, population based study. BMJ, 322:14471451 .

[59] Solomon A, Kivipelto M, Wolozin B, Zhou J, Whitmer RA (2009). Midlife serum cholesterol and increased risk of Alzheimer's and vascular dementia three decades later. Dement Geriatr Cogn Disord, 28:75-80.

[60] Evans RM, Emsley CL, Gao S, Sahota A, Hall KS, Farlow MR, et al (2000). Serum cholesterol, APOE genotype, and the risk of Alzheimer's disease: a population-based study of African Americans. Neurology, 54:240-242.

[61] Shepardson NE, Shankar GM, Selkoe DJ (2011). Cholesterol level and statin use in Alzheimer disease: I. Review of epidemiological and preclinical studies. Arch Neurol, 68:1239-1244.

[62] Ramdane S, Daoudi-Gueddah D (2011). Mild hypercholesterolemia, normal plasma triglycerides, and normal glucose levels across dementia staging in Alzheimer's disease: a clinical setting-based retrospective study. Am J Alzheimers Dis Other Demen, 26:399-405.

[63] Paragh G, Balla P, Katona E, Seres I, Egerházi A, Degrell I (2002). Serum paraoxonase activity changes in patients with Alzheimer's disease and vascular dementia. Eur Arch Psychiatry Clin Neurosci, 252:63-67.

[64] Mielke MM, Zandi PP, Shao H, Waern M, Östling S, Guo X, et al. (2010). The 32-year relationship between cholesterol and dementia from midlife to late life. Neurology, 75:1888-1895.

[65] Cedazo-Mínguez A, Ismail MA, Mateos L (2011). Plasma cholesterol and risk for late-onset Alzheimer's disease. Expert Rev Neurother, 11:495-498.

[66] Mielke MM, Zandi PP, Sjögren M, Gustafson D, Ostling S, Steen B et al. (2005). High total cholesterol levels in late life associated with a reduced risk of dementia. Neurology, 64:1689-1695. 
[67] Wolozin B, Kellman W, Ruosseau P, Celesia GG, Siegel G (2000). Decreased prevalence of Alzheimer disease associated with 3-hydroxy-3-methyglutaryl coenzyme A reductase inhibitors. Arch Neurol, 57:1439-1443.

[68] Scott HD, Laake K (2001). Statins for the prevention of Alzheimer's disease. Cochrane Database Syst Rev, 4:CD003160.

[69] Shepardson NE, Shankar GM, Selkoe DJ (2011). Cholesterol level and statin use in Alzheimer disease: II. Review of human trials and recommendations. Arch Neurol, 68:1385-1392.

[70] Wolozin B (2001). A fluid connection: cholesterol and Abeta. Proc Natl Acad Sci USA, 98:5371-5373.

[71] Puglielli L, Tanzi RE, Kovacs DM (2003). Alzheimer's disease: the cholesterol connection. Nat Neurosci. 6:345351.

[72] Umeda T, Tomiyama T, Kitajima E, Idomoto T, Nomura S, Lambert MP, et al. (2012). Hypercholesterolemia accelerates intraneuronal accumulation of $A \beta$ oligomers resulting in memory impairment in Alzheimer's disease model mice. Life Sci, 91:1169-1176.

[73] Bjorkhem I, Meaney S (2004). Brain cholesterol: long secret life behind a barrier. Arterioscler Thromb Vasc Biol, 24:806-815.

[74] Dietschy JM, Turley SD (2001). Cholesterol metabolism in the brain. Curr Opin Lipidol, 12:105-112.

[75] Simons M, Keller P, Dichgans J, Schulz JB (2001). Cholesterol and Alzheimer's disease: is there a link? Neurology, 57:1089-1093.

[76] Michikawa M, Fan QW, Isobe I, Yanagisawa K (2000). Apolipoprotein E exhibits isoform-specific promotion of lipid efflux from astrocytes and neurons in culture. $\mathrm{J}$ Neurochem, 74:1008-1016.

[77] Evans RM, Hui S, Perkins A, Lahiri DK, Poirier J, Farlow MR (2004). Cholesterol and APOE genotype interact to influence Alzheimer disease progre ssion. Neurology, 62:1869-1871.

[78] Zuliani G, Donnorso MP, Bosi C, Passaro A, Dalla Nora E, Zurlo A, et al. (2011). Plasma 24S-hydroxycholesterol levels in elderly subjects with late onset Alzheimer's disease or vascular dementia: a case-control study. BMC Neurol, 11:121.

[79] Vega GL, Weiner MF, Lipton AM, Von Bergmann K, Lutjohann D, Moore C, et al. (2003). Reduction in levels of 24S-hydroxycholesterol by statin treatment in patients with Alzheimer disease. Arch Neurol, 60:510-515.

[80] Leibson CL, Rocca WA, Hanson VA, Cha R, Kokmen E, O'Brien PC, et al. (1997). Risk of dementia among persons with diabetes mellitus: a population-based cohort study. Am J Epidemiol, 145:301-308.

[81] Ott A, Stolk RP, van Harskamp F, Pols HA, Hofman A, Breteler MM (1999). Diabetes mellitus and the risk of dementia: The Rotterdam Study. Neurology, 53:19371942.

[82] Brayne C, Gill C, Huppert FA, Barkley C, Gehlhaar E, Girling DM, et al. (1998). Vascular risks and incident dementia: results from a cohort study of the very old. Dement Geriatr Cogn Disord, 9:175-180.

[83] Peila R, Rodriguez BL, Launer LJ (2002). Type 2 diabetes, APOE gene, and the risk for dementia and related pathologies: the Honolulu-Asia aging study. Diabetes, 51:1256-1262.

[84] Li L, Holscher C (2007). Common pathological processes in Alzheimer disease and type 2 diabetes: a review. Brain Res Rev, 56:384-402.

[85] Luchsinger JA, Tang MX, Shea S, Mayeux R (2004). Hyperinsulinemia and risk of Alzheimer disease. Neurology, 63:1187-92.

[86] Luchsinger JA, Reitz C, Honig LS, Tang MX, Shea S, Mayeux R (2005). Aggregation of vascular risk factors and risk of incident Alzheimer disease. Neurology, 65:545-551.

[87] Cheng G, Huang C, Deng H, Wang H (2012). Diabetes as a risk factor for dementia and mild cognitive impairment: a meta-analysis of longitudinal studies. Intern Med J, 42:484-491.

[88] Exalto LG, Whitmer RA, Kappele LJ, Biessels GJ (2012). An update on type 2 diabetes, vascular dementia and Alzheimer's disease. Exp Gerontol, 47:858-864.

[89] Vagelatos NT, Eslick GD (2013). Type 2 diabetes as a risk factor for Alzheimer's disease: The confounders, interactions, and neuropathology associated with this relationship. Epidemiol Rev, 35:152-160.

[90] Luchsinger JA (2010). Diabetes, related conditions, and dementia. J Neurol Sci, 299:35-38.

[91] Kuusisto J, Koivisto K, Mykkanen L, Helkala EL, Vanhanen M, Hanninen T, et al. (1997). Association between features of the insulin resistance syndrome and Alzheimer's disease independently of apolipoprotein E4 phenotype: cross sectional population based study. BMJ, 315:1045-1049.

[92] Biessels GJ, Strachan MW, Visseren FL, Kappelle LJ, Whitmer RA (2014). Dementia and cognitive decline in type 2 diabetes and prediabetic stages: towards targeted interventions. Lancet Diabetes Endocrinol, 2:246-255.

[93] Reijmer YD, van den Berg E, Ruis C, Kappelle LJ, Biessels GJ (2010). Cognitive dysfunction in patients with type 2 diabetes. Diabetes Metab Res Rev, 26:507519 .

[94] McCrimmon RJ, Ryan CM, Frier BM (2012). Diabetes and cognitive dysfunction. Lancet, 379:2291-2299.

[95] Heitner J, Dickson D (1997). Diabetics do not have increased Alzheimer-type pathology compared with agematched control subjects. A retrospective post-mortem immunocytochemical and histofluorescent study. Neurology, 49:1306-1311.

[96] Ahtiluoto S, Polvikoski T, Peltonen M, Solomon A, Tuomilehto J, Winblad B et al (2010). Diabetes, Alzheimer disease, and vascular dementia: a populationbased neuropathologic study. Neurology, 75:1195-1202.

[97] Neumann KF, Rojo L, Navarrete LP, Farias G, Reyes P, Maccioni RB (2008). Insulin resistance and Alzheimer's disease: molecular links \& clinical implications.Curr Alzheimer Res, 5:438-447.

[98] De Felice FG (2013). Alzheimer's disease and insulin resistance: translating basic science into clinical applications. J Clin Invest, 123:531-539.

[99] Gasparini L, Gouras GK, Wang R, Gross RS, Beal MF, Greengard P, et al (2001). Stimulation of beta-amyloid precursor protein trafficking by insulin reduces 
intraneuronal beta-amyloid and requires mitogenactivated protein kinase signaling. J Neurosci, 21:25612570.

[100] Son SM, Song H, Byun J, Park KS, Jang HC, Park YJ, Mook-Jung I (2012). Altered APP processing in insulinresistant conditions is mediated by autophagosome accumulation via the inhibition of mammalian target of rapamycin pathway. Diabetes, 61:3126-3138.

[101] Correia SC, Santos RX, Carvalho C, Cardoso S, Candeias E, Santos MS, et al (2012). Insulin signaling, glucose metabolism and mitochondria: major players in Alzheimer's disease and diabetes interrelation. Brain Res, 1441:64-78.

[102] Yang Y, Song W (2013). Molecular links between Alzheimer's disease and diabetes mellitus. Neuroscience, 250: $140-150$.

[103] Tang J, Pei Y, Zhou G (2013). When aging-onset diabetes is coming across with Alzheimer disease: comparable pathogenesis and therapy. Exp Gerontol, 48:744-750

[104] Liu Y, Liu F, Grundke-Iqbal I, Iqbal K, Gong CX (2011). Deficient brain insulin signalling pathway in Alzheimer's disease and diabetes. J. Pathol, 225:54-62.

[105] Frolich L, Blum-Degen D, Bernstein HG, Engelsberger S, Humrich J, Laufer S, et al. (1998). Brain insulin and insulin receptors in aging and sporadic Alzheimer's disease. J Neural Transm, 105:423-438.

[106] Rivera EJ, Goldin A, Fulmer N, Tavares R, Wands JR, de la Monte SM (2005). Insulin and insulin-like growth factor expression and function deteriorate with progression of Alzheimer'sdisease: link to brain reductions in acetylcholine. J Alzheimers Dis, 8:247268.

[107] Steen E, Terry BM, Rivera EJ, Cannon JL, Neely TR, Tavares R, et al. (2005). Impaired insulin and insulinlike growth factor expression and signaling mechanisms in Alzheimer's disease--is this type 3 diabetes? J Alzheimers Dis. 7:63-80.

[108] Grunblatt E, Salkovic-Petrisic M, Osmanovic J, Riederer P, Hoyer S (2007). Brain insulin system dysfunction in streptozotocin intracerebroventricularly treated rats generates hyperphosphorylated tau protein. J Neurochem, 101: 757-770.

[109] Ho L, Qin W, Pompl PN, Xiang Z, Wang J, Zhao Z, et al. (2004). Diet-induced insulin resistance promotes amyloidosis in a transgenic mouse model of Alzheimer's disease. FASEB J, 18:902-904.

[110] Park SA (2011). A common pathogenic mechanism linking type-2 diabetes and Alzheimer's disease: evidence from animal models. J Clin Neurol, 7:10-18.

[111] Wallum BJ, Taborsky GJ Jr, Porte D Jr, Figlewicz DP, Jacobson L, Beard JC, et al. (1987). Cerebrospinal fluid insulin levels increase during intravenous insulin infusions in man. J Clin Endocrinol Metab, 64:190-194.

[112] Bosco D, Fava A, Plastino M, Montalcini T, Pujia A (2011). Possible implications of insulin resistance and glucose metabolism in Alzheimer's disease pathogenesis. J Cell Mol Med, 15:1807-1821.

[113] Freiherr J, Hallschmid M, Frey WH 2nd, Brünner YF, Chapman CD, Holscher C, et al. (2013). Intranasal insulin as a treatment for Alzheimer's disease: a review of basic research and clinical evidence. CNS Drugs, 27:505-514.

[114] Williamson R, McNeilly A, Sutherland C (2012). Insulin resistance in the brain: an old-age or new-age problem? Biochem Pharmacol, 84:737-745.

[115] Ciaccio M, Bellia C (2010). Hyperhomocysteinemia and cardiovascular risk: effect of vitamin supplementation in risk reduction. Curr Clin Pharmacol, 5:30-36.

[116] Maron BA, Loscalzo J (2009). The treatment of hyperhomocysteinemia. Annu Rev Med. 60:39-54.

[117] Zhuo JM, Wang H, Pratico D (2011). Is hyperhomocysteinemia an Alzheimer's disease (AD) risk factor, an AD marker, or neither? Trends Pharmacol Sci, 32:562-571.

[118] Seshadri S, Beiser A, Selhub J, Jacques PF, Rosenberg IH, D'Agostino RB, et al. (2002). Plasma homocysteine as a risk factor for dementia and Alzheimer's disease. $\mathrm{N}$ Engl J Med, 346:476-483.

[119] Zylberstein DE, Lissner L, Björkelund C, Mehlig K, Thelle DS, Gustafson D, et al (2009). Midlife homocysteine and late-life dementia in women. A prospective population study. Neurobiol Aging, 32:380386.

[120] Elias MF, Sullivan LM, D'Agostino RB, Elias PK, Jacques PF, Selhub J, et al. (2005). Homocysteine and cognitive performance in the Framingham offspring study: age is important. Am J Epidemiol, 162:644-653.

[121] Wald DS, Kasturiratne A, Simmonds M (2011). Serum homocysteine and dementia: meta-analysis of eight cohort studies including 8669 participants. Alzheimers Dement. 7:412-417.

[122] Clarke R, Smith AD, Jobst KA, Refsum H, Sutton L, Ueland PM (1998). Folate, vitamin B12, and serum total homocysteine levels in confirmed Alzheimer disease. Arch Neurol, 55:1449-1455.

[123] Mizrahi EH, Bowirrat A, Jacobsen DW, Korczyn AD, Traore F, Petot GJ, et al. (2004). Plasma homocysteine, vitamin B12 and folate in Alzheimer's patients and healthy Arabs in Israel. J Neurol Sci, 227:109-113.

[124] Postiglione A, Milan G, Ruocco A, Gallotta G, Guiotto G, Di Minno G (2001). Plasma folate, vitamin B(12), and total homocysteine and homozygosity for the C677T mutation of the 5,10-methylene tetrahydrofolate reductase gene in patients with Alzheimer's dementia. A case-control study. Gerontology, 47:324-329.

[125] Nilsson K, Gustafson L, Hultberg B (2012). Elevated plasma homocysteine level is not primarily related to Alzheimer's disease. Dement Geriatr Cogn Disord, 34:121-127.

[126] Seshadri S (2006). Elevated plasma homocysteine levels: risk factor or risk marker for the development of dementia and Alzheimer's disease? J Alzheimers Dis, 9:393-398.

[127] Aisen PS, Schneider LS, Sano M, Diaz-Arrastia R, van Dyck CH, Weiner MF, et al. (2008). High-dose B vitamin supplementation and cognitive decline in Alzheimer disease: a randomized controlled trial. JAMA, 300: 1774-1783. 
[128] Sun Y, Lu CJ, Chien KL, Chen ST, Chen RC (2007). Efficacy of multivitamin supplementation containing vitamins B6 and B12 and folic acid as adjunctive treatment with a cholinesterase inhibitor in Alzheimer's disease: a 26-week, randomized, double-blind, placebocontrolled study in Taiwanese patients. Clin Ther, 29:2204-2214.

[129] Miller JW, Green R, Mungas DM, Reed BR, Jagust WJ (2006). Homocysteine, vitamin B6, and vascular disease in AD patients. Neurology, 58:1471-1475.

[130] Ray L, Khemka VK, Behera P, Bandyopadhyay K, Pal S, Pal K, et al. (2013).Serum homocysteine, dehydroepiandrosterone sulphate and lipoprotein (a) in Alzheimer's disease and vascular dementia. Aging Dis, 4:57-64.

[131] Obeid R, Herrmann W (2006). Mechanisms of homocysteine neurotoxicity in neurodegenerative diseases with special reference to dementia. FEBS Lett, 580:2994-3005.

[132] Lin N, Qin S, Luo S, Cui S, Huang G, Zhang X (2014). Homocysteine induces cytotoxicity and proliferation inhibition in neural stem cells via DNA methylation in vitro. FEBS J, 281:2088-2096.

[133] Kim WK, Pae YS (1996). Involvement of N-methyl-daspartate receptor and free radical in homocysteinemediated toxicity on rat cerebellar granule cells in culture. Neurosci Lett, 216:117-120.

[134] Chandran M, Phillips SA, Ciaraldi T, Henry RR (2003). Adiponectin: more than just another fat cell hormone? Diabetes Care, 26:2442-2450.

[135] Yamauchi T, Kamon J, Minokoshi Y, Ito Y, Waki H, Uchida S, et al. (2002). Adiponectin stimulates glucose utilization and fatty-acid oxidation by activating AMPactivated protein kinase. Nat Med, 8:1288-1295.

[136] Soodini GR (2004). Adiponectin and leptin in relation to insulin sensitivity. Metab Syndr Relat Disord, 2:114123.

[137] Thundyil J, Pavlovski D, Sobey CG, Arumugam TV (2012). Adiponectin receptor signalling in the brain. Br J Pharmacol, 165:313-327.

[138] 138. Morton GJ (2007). Hypothalamic leptin regulation of energy homeostasis and glucose metabolism. J Physiol, 583:437-443.

[139] Marwarha G, Ghribi O (2012). Leptin signaling and Alzheimer's disease. Am J Neurodegener Dis, 1:245265.

[140] Lee EB (2011). Obesity, leptin, and Alzheimer's disease. Ann N Y Acad Sci, 1243:15-29.

[141] Lieb W, Beiser AS, Vasan RS, Tan ZS, Au R, Harris TB, et al. (2009). Association of plasma leptin levels with incident Alzheimer disease and MRI measures of brain aging. JAMA, 302:2565-2572.

[142] Holden KF, Lindquist K, Tylavsky FA, Rosano C, Harris TB, Yaffe K (2009). Serum leptin level and cognition in the elderly: Findings from the Health ABC Study. Neurobiol Aging, 30:1483-1489.

[143] Rizoulis AA, Karaoulanis SE, Rizouli KA, Papadimitriou A (2005). Serum leptin levels in patients with Alzheimer's disease. Int J Caring Sci, 5:43-49.
[144] Une K, Takei YA, Tomita N, Asamura T, Ohrui T, Furukawa K, et al. (2011). Adiponectin in plasma and cerebrospinal fluid in MCI and Alzheimer's disease. Eur J Neurol, 18:1006-1009.

[145] van Himbergen TM, Beiser AS, Ai M, Seshadri S, Otokozawa S, Au R, et al. (2012). Biomarkers for insulin resistance and inflammation and the risk for all-cause dementia and alzheimer disease: results from the Framingham Heart Study. Arch Neurol, 69:594-600.

[146] Warren MW, Hynan LS, Weiner MF (2012). Lipids and adipokines as risk factors for Alzheimer's disease. J Alzheimers Dis, 29:151-157.

[147] Tezapsidis N, Johnston JM, Smith MA, Ashford JW, Casadesus G, Robakis NK, et al. (2009). Leptin: A novel therapeutic strategy for Alzheimer's disease. J Alzheimers Dis, 16:731-740.

[148] Smith JA, Das A, Ray SK, Banik NL (2012). Role of proinflammatory cytokines released from microglia in neurodegenerative diseases. Brain res bull, 87:10 -20.

[149] Enciu AM, Popescu BO (2013). Is there a causal link between Inflammation and dementia? Biomed Res Int, 2013:316495.

[150] Akiyama H, Barger S, Barnum S, Bradt B, Bauer J, Cole GM, et al. (2000). Inflammation and Alzheimer's disease. Neurobiol Aging, 21:383-421.

[151] Weisman D, Hakimian E, and Ho GJ (2006). Interleukins, inflammation, and mechanisms of Alzheimer's disease. Vitam Horm, 74:505-530.

[152] Rubio-Perez JM and Morillas-Ruiz JM (2012). A review: Inflammatory process in Alzheimer's disease, Role of cytokines. Scientific World Journal, 2012: 756357.

[153] Heneka MT, Kummer MP, Stutz A, Delekate A, Schwartz S, Vieira-Saecker A, et al. (2013). NLRP3 is activated in Alzheimer's disease and contributes to pathology in APP/PS1 mice. Nature, 493:674-678.

[154] Tan MS, Yu JT, Jiang T, Zhu XC, Tan L (2013). The NLRP3 inflammasome in Alzheimer's disease. Mol Neurobiol, 48:875-882.

[155] Licastro F, Pedrini S, Caputo L, Annoni G, Grimaldi LME (2000). Increased plasma levels of interleukin-1, interleukin- 6 and $\alpha$-1-antichymotrypsin in patients with Alzheimer's disease: peripheral inflammation or signals from the brain? J Neuroimmunol, 103:97-102.

[156] Mraka RE, Griffin WST (2005). Potential Inflammatory biomarkers in Alzheimer's disease. J Alzheimers Dis, 8:369-375.

[157] Lee KS, Chung JH, Choi TK, Suh SY, Oh BH, Hong CH (2009). Peripheral cytokines and chemokines in Alzheimer's disease. Dement Geriatr Cogn Disord, 28:281-287.

[158] Lanzrein A, Johnston CM, Perry VH, Jobst KA, King EM, Smith AD (1998). Longitudinal study of inflammatory factors in serum, cerebrospinal fluid, and brain tissue in Alzheimer disease: interleukin-1 $\beta$, interleukin-6, interleukin-1 receptor antagonist, tumor necrosis factor- $\alpha$, the soluble tumor necrosis factor receptors I and II, and $\alpha 1$ antichymotrypsin. Alzheimer Dis Assoc Disord, 12: 215-227. 
[159] Swardfager W, Lanctôt K, Rothenburg L, Wong A, Cappell J,Herrmann N (2010). A meta-analysis of cytokines in Alzheimer's disease. Biol Psychiatry, 68:930-941.

[160] Khemka VK, Ganguly A, Bagchi D, Ghosh A, Bir A, Biswas A, et al. (2014). Raised serum proinflammatory cytokines in Alzheimer's disease with depression. Aging Dis, 5:170-176.

[161] Banks WA, Farr SA, Morley JE (2002). Entry of BloodBorne Cytokines into the Central Nervous System: Effects on Cognitive Processes. Neuroimmunomodulation, 10:319-327.

[162] Vitkovic L, Konsman JP, Bockaert J, Dantzer R, Homburger V, Jacque C (2000). Cytokine signals propagate through the brain. Mol Psychiatry, 5:604-615.

[163] McAfoose J, Baune BT (2009). Evidence for a cytokine model of cognitive function. Neurosci Biobehav Rev, 33:355-366.

[164] Godbout JP, Chen J, Abraham J, Richwine AF, Berg BM, Kelley KW, et al. (2005). Exaggerated neuroinflammation and sickness behavior in aged mice following activation of the peripheral innate immune system. FASEB J, 19:1329-1331.

[165] Kelley KW, Bluthe RM, Dantzer R, Zhou JH, Shen WH, Johnson RW, et al. (2003). Cytokine-induced sickness behavior. Brain Behav Immun, 17 Suppl 1:S112-118.

[166] Reichenberg A, Yirmiya R, Schuld A, Kraus T, Haack M, Morag A, et al. (2001). Cytokine-associated emotional and cognitive disturbances in humans. Arch Gen Psychiatry, 58:445-452.

[167] Dantzer R, O'Connor JC, Freund GG, Johnson RW, Kelley KW (2008). From inflammation to sickness and depression: when the immune system subjugates the brain. Nat Rev Neurosci, 9:46-56.

[168] Galic MA, Riazi K, Pittman QJ (2012). Cytokines and brain excitability. Front Neuroendocrinol, 33:116-125.

[169] Shaftel SS, Griffin WS, O'Banion MK (2008). The role of interleukin-1 in neuroinflammation and Alzheimer disease: an evolving perspective. J Neuroinflammation, 5:7.

[170] Blasko I, Marx F, Steiner E, Hartmann T, GrubeckLoebenstein B (1999). TNF alpha plus IFN gamma induce the production of Alzheimer beta-amyloid peptides, and decrease the secretion of APPs. FASEB J, 13:63-68.

[171] Jones G, Strugnell SA, DeLuca HF (1998). Current understanding of the molecular actions of vitamin $\mathrm{D}$. Physiol Rev, 78:1193-1231.

[172] Revelli A, Massobrio M, Tesarik J (1998). Nongenomic effects of 1 alpha, 25-dihydroxyvitamin $\mathrm{D}_{3}$. Trends Endocrinol Metab, 9:419-427.

[173] 173. Wrzosek M, Łukaszkiewicz J, Wrzosek M, Jakubczyk A, Matsumoto $\mathrm{H}$, Piątkiewicz $\mathrm{P}$, et al. (2013).Vitamin D and the central nervous system. Pharmacol Rep, 65:271-278.

[174] Eyles DW, Burne TH, McGrath JJ (2013).Vitamin D, effects on brain development, adult brain function and the links between low levels of vitamin $\mathrm{D}$ and neuropsychiatric disease. Front Neuroendocrinol, 34:4764.

[175] Garcion E, Wion-Barbot N, Montero-Menei CN, Berger F, Wion D (2002). New clues about vitamin D functions in the nervous system. Trends Endocrinol Metab, 13:100-105.

[176] Gezen-Ak D, Dursun E, Ertan T, Hanağasi H, Gürvit H, Emre M, et al. (2007). Association between vitamin D receptor gene polymorphism and Alzheimer's disease. Tohoku J Exp Med, 12:275-282.

[177] Wang L, Hara K, Van Baaren JM, Price JC, Beecham GW, Gallins PJ, et al. (2012).Vitamin D receptor and Alzheimer's disease: a genetic and functional study. Neurobiol Aging, 33:1844.e1-9.

[178] Gezen-Ak D, Dursun E, Bilgiç B, Hanağasi H, Ertan T, Gürvit H, et al. (2012). Vitamin D receptor gene haplotype is associated with late-onset Alzheimer's disease. Tohoku J Exp Med, 228:189-196.

[179] Annweiler C, Llewellyn DJ, Beauchet O (2013). Low serum vitamin $\mathrm{D}$ concentrations in Alzheimer's disease: a systematic review and meta-analysis. J Alzheimers Dis, 33:659-674.

[180] Zhao Y, Sun Y, Ji HF, Shen L (2013). Vitamin D levels in Alzheimer's and Parkinson's diseases: a meta-analysis. Nutrition, 29:828-832.

[181] Afzal S, Bojesen SE, Nordestgaard BG (2014). Reduced 25-hydroxyvitamin D and risk of Alzheimer's disease and vascular dementia. Alzheimers Dement, 10:296-302.

[182] Hooshmand B, Lokk J, Solomon A, Mangialasche F, Miralbell J, Spulber G, et al. (2014). Vitamin D in relation to cognitive impairment, cerebrospinal fluid biomarkers, and brain volumes. J Gerontol A Biol Sci Med Sci, doi: 10.1093/gerona/glu022 [Epub ahead of print].

[183] Dursun E, Gezen-Ak D, Yilmazer S (2011). A novel perspective for Alzheimer's disease: vitamin D receptor suppression by amyloid- $\beta$ and preventing the amyloid- $\beta$ induced alterations by vitamin D in cortical neurons. J Alzheimers Dis, 23:207-219.

[184] Sutherland MK, Somerville MJ, Yoong LK, Bergeron C, Haussler MR, McLachlan DR (1992). Reduction of vitamin D hormone receptor mRNA levels in Alzheimer as compared to Huntington hippocampus: correlation with calbindin-28k mRNA levels. Brain Res Mol Brain Res, 13:239-250.

[185] Ito S, Ohtsuki S, Nezu Y, Koitabashi Y, Murata S, Terasaki T (2011). 1 alpha, 25-dihydroxyvitamin $\mathrm{D}_{3}$ enhances cerebral clearance of human amyloid- $\beta$ peptide (1-40) from mouse brain across the blood-brain barrier. Fluids Barriers CNS, 8:20.

[186] Masoumi A, Goldenson B, Ghirmai S, Avagyan H, Zaghi J, Abel K, et al. (2009). 1 alpha, 25dihydroxyvitamin $\mathrm{D}_{3}$ interacts with curcuminoids to stimulate amyloid-beta clearance by macrophages of Alzheimer's disease patients. J Alzheimers Dis, 17:703717.

[187] Yu J, Gattoni-Celli M, Zhu H, Bhat NR, Sambamurti K, Gattoni-Celli S, et al. (2011).Vitamin $\mathrm{D}_{3}$-enriched diet correlates with a decrease of amyloid plaques in the brain of A $\beta P P$ transgenic mice. J Alzheimers Dis, 25:295-307. 
[188] Jiang T, Yu JT, Tan L (2012). Novel disease-modifying therapies for Alzheimer's disease. J Alzheimers Dis, 31: 475-492.
[189] Townsend M (2011). When will Alzheimer's disease be cured? A pharmaceutical perspective. J Alzheimers Dis, 24 Suppl 2:43-52. 